\title{
Incidence and Fetal Outcomes of HIV/Aids Patients at Hasan Sadikin General Hospital
}

\author{
Anita Rachmawati1, Johannes C. Mose'1, Hasan Sadikin² \\ ${ }^{1}$ Department of Obstetrics and Gynecology, Faculty of Medicine, Padjadjaran University, Bandung, Indonesia \\ ${ }^{2}$ General Hospital Bandung, Bandung, Indonesia \\ Email: arspog2000@gmail.com
}

How to cite this paper: Rachmawati, A., Mose, J.C. and Sadikin, H. (2017) Incidence and Fetal Outcomes of HIV/Aids Patients at Hasan Sadikin General Hospital. Open Access Library Journal, 4: e3704. https://doi.org/10.4236/oalib.1103704

Received: May 31, 2017

Accepted: July 24, 2017

Published: July 27, 2017

Copyright $\odot 2017$ by authors and Open Access Library Inc.

This work is licensed under the Creative Commons Attribution International License (CC BY 4.0). http://creativecommons.org/licenses/by/4.0/

\section{Open Access}

\begin{abstract}
Introduction: The increasing number of HIV/AIDS incidence over time begins to become global problems. One of the current concerns is the morbidity and mortality rates in the fetal outcomes patients with HIV/AIDS who can provide many complications. The importance of adequate pre- and antenatal care may help to reduce morbidity and mortality due to this condition. The purpose of this study is to determine incidence and morbidity of mother with HIV/AIDS and fetal outcomes after delivery in Hasan Sadikin General Hospital from 2011 to 2015. Method: With descriptive study, we use secondary data from medical record on Obstetrics and Gynecology Department. Results of fetal outcomes obtained from medical record on Perinatology Department and the management of HIV/AIDS in married couples and fetal after delivery was obtained from medical record on Teratai Clinic, Hasan Sadikin General Hospital. Results: The incidence of mother with HIV/AIDS who gave birth at Hasan Sadikin General Hospital from 2011 to 2015 tends to increase every year with the number of percentage is $0.06 \%, 0.29 \%, 0.24 \%, 0.72 \%$, and $0.38 \%$ from total deliveries, respectively. Fetal outcomes vary from preterm labour $19.57 \%$, low birth weight baby $15.22 \%$, asphyxia $13.04 \%$, small for gestational age (SGA) $4.35 \%$, and early fetal death $2.17 \%$. Conclusion: Incidence of delivery with HIV/AIDS tends to increase every year. Preterm labor has the highest morbidity on fetal outcomes.
\end{abstract}

\section{Subject Areas \\ HIV}

\section{Keywords}

Incidence, Morbidity, HIV/AIDS, Fetal Outcomes

\section{Introduction}

HIV/AIDS become a global problem because until 2014, almost 36.9 million 
people have been affected by HIV. In 2012, around 17.2 million people with HIV/AIDS was male, 19.2 million was female, and 3.4 million among them were under 15 years [1]. Total mortality due to AIDS was 1.5 million which consist of 1.3 million adult and 190.000 people under 15 years.

In Indonesia, HIV firstly reported on 1987 and there was a tendency to increase the number of HIV cases every year. Cumulative number of HIV patients from 1987 to March 2016 is 198.219, and total cumulative number of all AIDS cases is 78.292. This case is reported to spread under 386 city and district on all of provinces in Indonesia with West Java as the fourth position after DKI Jakarta, East Java and Papua [2] [3].

Most of HIV/AIDS patients are at age $20-49$ (73\%) with 55\% of them is male and $31 \%$ is female. Based on work, most of those patients are housewives (10.691), and it's associated with the highest transmission risk factors dominated by heterosexuals $(73.8 \%)$ [2].

Fetal mortality has been associated to be one of the consequences of delivery in HIV patients. Nearly $99 \%$ of neonatal deaths every year, occur in low income countries [4].Transmission of HIV from mother to fetus is the final way of chain transmission started from suspected HIV-positive man to his partner with unsafe sexual intercourse then transmitted to the baby. Without interventions, the transmission risk from mother to fetus has been reported between $20 \%-50 \%$. Transmission can occur in the beginning of pregnancy, intrapartum, or post partum. Most of the transmission occur in the intrapartum period (10\% - 20\%).

With the prevention of HIV transmission from mother to fetus, the risk decreased almost into 2\% [3]. Besides the risk of HIV infection, pregnant women with HIV are associated with an increased risk of preterm labor, low birth weight, and small for gestational age that contribute to neonatal mortality [5]. And in many countries in Africa, HIV has become the most potent cause of preterm birth. That is the reason why it is so important that management of HIV infected pregnancy through antenatal care has been addressed to improve quality of fetal outcomes.

HIV-infected fetus will face complex problem on throughout their life. An HIV infected fetus will experience many health and development problems. Research in many countries shows that child who born from HIV-positive mother, significantly increase the risk of morbidity and mortality.

Big consequence of this HIV infection is a large impact on society and huge economic and social burden. The information on fetal outcomes and factors contributing to the occurrence of HIV/AIDS will provide the necessary way to suppress the rate of HIV/AIDS development.

Based on description above, the researcher interested to know the incidence of labor, maternal morbidity, and fetal outcome in HIV/AIDS patients at Hasan Sadikin General Hospital.

\section{Methods}

This study was using descriptive approach, we use secondary data from medical 
record on Hasan Sadikin General Hospital on December 2016. After data has been conducted from medical records, it will be recorded in a special form that presented in tables and graphs. The data that we collected is taken from each section, including mother medical records in maternity Obstetrics and Gynecology Departments, fetal medical records from Perinatology Department and HIV/AIDS treatment medical records derived from Teratai Clinic Hasan Sadikin General Hospital Bandung.

Inclusion criteria for mother in our study are all HIV-pregnant patients who already have done labor and recorded completely in Hasan Sadikin General Hospital Bandung from 2011 to 2015. Inclusion criteria for fetus are all of them who born from HIV-pregnant patients and recorded completely in Hasan Sadikin General Hospital Bandung from 2011 to 2015. Exclusion criteria is all mothers and fetus which is not perfectly recorded so that data can't be used for the parameters we evaluated.

In our study, we collect these variables, 1) incidence: including here all recorded labor events either vaginal delivery, assisted vaginal delivery, or caesarean section; 2) mothers: including characteristic and prenatal care; 3) fetus: including fetal weight, live birth, stillbirth, fetal death, and HIV-infected fetal.

This study had been approved by Padjadjaran University Ethical Committee. Data will be processed descriptively and presented in table containing amount and percentage. Once collected, data are selected based on the inclusion criteria. We combine all data from mothers, infants, and HIV/AIDS therapies, and if any of the data is incomplete, other related data will not be used.

\section{Results}

In this study, we collected as many as 45 data from medical records that fit in our inclusion criteria. From these data, we present it into several table, namely mothers and partners characteristics, HIV/AIDS related birthrate incidence, HIV/AIDS delivery method, and HIV/AIDS fetal outcomes.

The majority of patients age is ranged between 25 - 30 years $(55.56 \%)$. The longest education time is 9 - 12 years (51.11\%). Highest parity is one child (46.67\%). Almost all patients undergoing antenatal care for more than 4 times (91.11\%). The majority of residences are in the city of Bandung (57.78\%). And most common jobs are housewives (82.22\%) (Table 1).

The majority of partners age is between $>30$ years $(46.91 \%)$. The longest education time is $9-12$ years $(53.33 \%)$. The majority of residences are in the city of Bandung (57.78\%). And most common jobs are private employees $(82.22 \%)$ (Table 2).

The incidence of woman with HIV/AIDS who have done labor in Hasan Sadikin General Hospital from 2011 to 2015 tend to increased every year with the number of percentage, respectively were $0.06 \%, 0.29 \%, 0.24 \%, 0.72 \%$, and $0.38 \%$ from total deliveries (Table 3). 
Table 1. Characteristics of HIV-pregnant patients who have done labor in Hasan Sadikin general hospital from 2011 to 2015.

\begin{tabular}{|c|c|c|c|}
\hline No & Characteristics & Total $(n=45)$ & Percentage (\%) \\
\hline \multirow{5}{*}{1} & Age & & \\
\hline & $<20$ years & 1 & $2.22 \%$ \\
\hline & $20-24$ years & 11 & $24.44 \%$ \\
\hline & 25 - 30 years & 25 & $55.56 \%$ \\
\hline & $>30$ years & 8 & $17.78 \%$ \\
\hline \multirow{5}{*}{2} & Length of education & & \\
\hline & $0-6$ years & 9 & $20.00 \%$ \\
\hline & $7-9$ years & 5 & $11.11 \%$ \\
\hline & $9-12$ years & 23 & $51.11 \%$ \\
\hline & $>12$ years & 8 & $17.78 \%$ \\
\hline \multirow{4}{*}{3} & Parity & & \\
\hline & 1 & 21 & $46.67 \%$ \\
\hline & 2 & 18 & $45.00 \%$ \\
\hline & $\geq 3$ & 6 & $13.33 \%$ \\
\hline \multirow{3}{*}{4} & Number of attendance (antenatal car & & \\
\hline & $<4$ & 4 & $8.88 \%$ \\
\hline & $\geq 4$ & 41 & $91.11 \%$ \\
\hline \multirow{4}{*}{5} & Residence & & \\
\hline & Bandung city & 26 & $57.78 \%$ \\
\hline & Bandung district & 11 & $24.44 \%$ \\
\hline & Outside Bandung city and district & 8 & $17.78 \%$ \\
\hline \multirow{6}{*}{6} & Employment & & \\
\hline & Housewives & 37 & $82.22 \%$ \\
\hline & Government employees & 1 & $2.22 \%$ \\
\hline & Private employees & 3 & $6.67 \%$ \\
\hline & Entrepreneur & 3 & $6.67 \%$ \\
\hline & Others & 1 & $2.22 \%$ \\
\hline
\end{tabular}

Table 2. Characteristics from partners of HIV-pregnant patients who have done labor in Hasan Sadikin general hospital from 2011 to 2015.

\begin{tabular}{cccc}
\hline No. & Characteristics & Total $(\mathbf{n}=45)$ & Percentage (\%) \\
\hline Age & & \\
& $<20$ years & 0 & $0.00 \%$ \\
1. & 10 & $22.22 \%$ \\
& $20-24$ years & 14 & $31.11 \%$ \\
& $24-29$ years & 21 & $46.91 \%$ \\
\hline
\end{tabular}




\section{Continued}

\begin{tabular}{ccc}
\hline Length of education & & \\
$0-6$ years & 9 & $20.00 \%$ \\
7 - 9 years & 3 & $6.67 \%$ \\
$9-12$ years & 24 & $53.33 \%$ \\
$>12$ years & 9 & $20.00 \%$ \\
Residence & & \\
Inside Bandung city & 26 & $57.78 \%$ \\
Inside Bandung district & 11 & $24.44 \%$ \\
Outside Bandung city and district & 8 & $17.78 \%$ \\
Employment & & \\
Government employees & 0 & $0.00 \%$ \\
Private employees & 30 & $66.67 \%$ \\
Honorary laborer & 15 & $33.33 \%$ \\
\hline
\end{tabular}

Table 3. The incidence of HIV/AIDS pregnancy undergoing labor on Hasan Sadikin general hospital from 2011 to 2015.

\begin{tabular}{ccccc}
\hline No. & Year & $\begin{array}{c}\text { Number of } \\
\text { Deliveries }\end{array}$ & $\begin{array}{c}\text { Delivery with } \\
\text { HIV/AIDS (n=) }\end{array}$ & Percentage (\%) \\
\hline 1 & 2011 & 1687 & 1 & $0.06 \%$ \\
2 & 2012 & 2047 & 6 & $0.29 \%$ \\
3 & 2013 & 2862 & 7 & $0.24 \%$ \\
4 & 2014 & 2639 & 19 & $0.72 \%$ \\
5 & 2015 & 3175 & 12 & $0.38 \%$ \\
\hline
\end{tabular}

Most of delivery methods performed are cesarean section (86.67\%), followed by vaginal delivery (11.11\%) and assisted vaginal delivery (2.22\%) (Table 4).

Most maternal prenatal place take place in obstetrician (51.11\%), and the others is midwife (40.00\%) and physician (8.89\%) (Table 5).

The most common fetal birthweight is ranged between 2500 - 2900 grams with the percentage 63.04 . And the incidence of low birth weight is $15.22 \%$, preterm labor around $19.57 \%$, small for gestational age is $4.35 \%$, born with asphyxia $13.04 \%$, and early fetal death is $2.17 \%$.

Number of patients that can be traced on medical record from Teratai Clinic Hasan Sadikin General Hospital, is 21 patients (46.67\%) from all HIV-pregnant patients who have done labor (Table 6).

\section{Discussion}

The incidence of woman with HIV/AIDS who has done labor in Hasan Sadikin General Hospital from 2011 to 2015 tends to increase every year with the number of percentage, respectively was $0.06 \%, 0.29 \%, 0.24 \%, 0.72 \%$, and $0.38 \%$ from total deliveries. The incidence in 2011 is lower than incidence in 2010, it can happen 
A. Rachmawati et al.

Table 4. Delivery method of HIV/AIDS patients in Hasan Sadikin general hospital from 2011 to 2015.

\begin{tabular}{ccccccccc}
\hline No. & Delivery Method & 2011 & $\mathbf{2 0 1 2}$ & $\begin{array}{c}\text { Tahun } \\
\text { 2013 }\end{array}$ & $\mathbf{2 0 1 4}$ & $\mathbf{2 0 1 5}$ & $\begin{array}{c}\text { Jumlah } \\
(\mathrm{n}=45)\end{array}$ & $\begin{array}{c}\text { Persentase } \\
(\%)\end{array}$ \\
\hline 1 & Vaginal delivery & 1 & 0 & 0 & 3 & 1 & 5 & $11.11 \%$ \\
2 & Assisted vaginal delivery & 0 & 0 & 0 & 0 & 1 & 1 & $2.22 \%$ \\
3 & Cesarean section & 0 & 6 & 7 & 16 & 10 & 39 & $86.67 \%$ \\
\hline
\end{tabular}

Table 5. Mother's prenatal care.

\begin{tabular}{cccc}
\hline No. & Prenatal Care & Total $(\mathrm{n}=45)$ & Percentage (\%) \\
\hline 1 & Midwife & 18 & $40.00 \%$ \\
2 & Physician & 4 & $8.89 \%$ \\
3 & Obstetrician & 23 & $51.11 \%$ \\
4 & No Prenatal Care & 0 & $0.00 \%$ \\
\hline
\end{tabular}

Table 6. Fetal outcomes.

\begin{tabular}{|c|c|c|c|}
\hline No & Fetal Outcomes & Total $(n=46)$ & Percentage (\%) \\
\hline \multirow{8}{*}{1} & Birthweight & & \\
\hline & 500 - 995 grams & 0 & $0.00 \%$ \\
\hline & $1000-1499$ grams & 0 & $0.00 \%$ \\
\hline & 1500 - 1999 grams & 2 & $4.35 \%$ \\
\hline & $2000-2499$ grams & 5 & $10.87 \%$ \\
\hline & 2500 - 2999grams & 29 & $63.04 \%$ \\
\hline & 3000 - 3499 grams & 9 & $19.57 \%$ \\
\hline & $>3500$ grams & 1 & $2.17 \%$ \\
\hline \multirow{2}{*}{2} & Live birth & 46 & $100.00 \%$ \\
\hline & Stillbirth & 0 & $0.00 \%$ \\
\hline \multirow{3}{*}{3} & Gestational Age & & \\
\hline & Aterm & 37 & $80.43 \%$ \\
\hline & Preterm & 9 & $19.57 \%$ \\
\hline \multirow{2}{*}{4} & Appropriate for gestational age & 44 & $95.65 \%$ \\
\hline & Small for gestational age & 2 & $4.35 \%$ \\
\hline \multirow{2}{*}{5} & No asphyxia & 40 & $86.96 \%$ \\
\hline & Asphyxia & 6 & $13.04 \%$ \\
\hline \multirow{3}{*}{6} & No fetal death & 45 & $97.83 \%$ \\
\hline & Early fetal death & 1 & $2.17 \%$ \\
\hline & Late fetal death & 0 & $0.00 \%$ \\
\hline
\end{tabular}


because of several possibilities, for example, women with HIV/AIDS often check themselves and do labor on another place other than Hasan Sadikin General Hospital. This is due to an increase in the number of hospitals either governmental or private who receive referrals of HIV/AIDS patients. Another possibility is that the patients who plan to give birth are not aware of their HIV status, even they tend to hide from HIV's stigma, or overall there is a decrease in HIV/ AIDS cases.

Most of deliveries are done with caesarean section, almost $86.67 \%$, followed by vaginal birth $11.11 \%$ and assisted vaginal delivery $2.22 \%$. All vaginal deliveries and assisted vaginal delivery happen, when patients came in the second stage of labor. The risk of vertical transmission from mother to fetus will be reduced by performing caesarean section before the onset of labor started and before rupture of membranes happen. And of course caesarean section in this case should be scheduled. The correlation between process of delivery and the risk of vertical transmission among this condition has been done and gave inconsistent results. Multiple studies from prospective cohort [6] [7], international randomized trial [8], and meta-analysis of individual patient's data from 15 prospective cohort studies include more than 7800 mothers-child pairs [9], found that there was a significant relationship between the process of delivery and vertical transmission of HIV. Based on our findings, which collected before the use of Highly Active Antiretroviral Therapy (HAART) and without looking any maternal viral load, it showed that the indication of scheduled caesarean delivery reduced the risk of vertical transmission of HIV compared with unscheduled ones or even vaginal delivery.

Most of patient's ages are 25 - 30 years old, with 55.56\%, while her partner's age is above 30 years old, with $46.91 \%$. In Indonesia, age distribution of HIV/AIDS patients in 2016 was represented by the younger age. With an addition from 20 29 years old that reached $31.5 \%$ and until 49 years, it can reach almost $73.1 \%$. The high percentage of young age may increase the risk of transmission to mothers and pregnancy.

The education level owned by patient majority is in $9-12$ old, both mother (51.11\%) and husband (53.33\%) This education level is needed when providing information and education counseling for people living with HIV/ AIDS. This is primarily related to the complex problems need to be faced, not only the medical problems but also social and economic problems. On previous study, it has found that the most frequent reason answered by people with HIV/AIDS to hide their status is due to stigma and alienation [10]. Then because of that stigma, they are facing a complex problem that may worsen their condition like psychologic and social problem during diagnosis, treatment and progression. In other previous studies also has been shown that having a family member with HIV positive can affect all family members inside with different ways [11]. In Turki, HIV's stigma problem always comes with other problem like employment, health, and education [12]. In fact, this happens not just in one place, the stigma about HIV has been globally and happened to many of people living with HIV 
(PLHIV) [13]. The most important step to solve this stigma's problems is educating the patients and their families [14].

The highest parity from all patients is 1 child, with 21 patients $(46.67 \%)$, following by 2 children, with 18 patients (45.00\%) and 3 children or above, with 6 patients (13.33\%). The highest number of antenatal care attendance is 4 attendance or more, with 41 patients $(91.11 \%)$. This attendance has been reported by WHO Antenatal Guidelines [15] for pregnant women to perform more than four times at specified intervals, at least for healthy pregnant women without underlying medical problems. For HIV-pregnant patients, they should be completed at least 4 antenatal care visit more than normal pregnant women with no underlying risk.

The great majority of occupations in HIV/AIDS patients are housewives, while the majority of occupation on the partner is a private employee. The distribution of AIDS sufferers in Indonesia by sex is mostly male (73.75\%). This characteristic when associated with the distribution of AIDS patients in Indonesia will provide a picture of some possible sources of HIV/AIDS. Men who work as private employees usually allow potential conditions of HIV risk factors around him such as free sexual intercourse or injected drug user. A housewife women can be infected with HIV, can potentially also get into this transmission chain.

Prenatal care of most patients are in obstetrician $(51.11 \%)$, the others choose midwife (40\%) and general physician (8.89\%). The data illustrates that women with HIV/AIDS doing labor in Hasan Sadikin General Hospital mostly have a fairly high awareness of her status by doing prenatal care in obstetrician. Test of anti-HIV should become a routine screening even if no risk factors in that pregnant women. It is necessary for the benefit of maternal and fetal health as well as the management of pregnancy and childbirth to reduce the transmission of HIV/ AIDS. However, these efforts are not easily realized. Psychological constraints and social views surrounding people with HIV/AIDS are often making them uncomfortable so they feel better to hide their condition and choosing to never tell their HIV status.

In the fetal outcome, we found the following results: low birth weight, $15.22 \%$; small for gestational age, $4.35 \%$; preterm birth, $19.57 \%$; and early neonatal death, $2.17 \%$. This data is consistent with some studies. Almost all of neonatal deaths in worldwide, have been caused by preterm births [16]. Study from Canada, which found from 2626 deliveries, about 427 live births were premature infants. Among births in HIV-positive women, $13 \%$ were gestational 32 to 36 weeks, $2 \%$ at 28 to 31 weeks, and $1 \%$ less than 28 weeks. Zack et al. [17] also found same results, based on their prospective study in 2014, they found $24 \%$ from 927 deliveries in HIV-infected pregnant women living in Dar es Salaam, Tanzania were born premature, moreover almost $9 \%$ of all deliveries were very premature. Zack et al. also found that this prematurity rate is higher than that found in other HIV infected populations. They compared their study with others. Ezechi et al. found from their study, $11 \%$ of 1626 HIV positive Nigerian women from 2004-2010 
were preterm delivery rate [18]. Another previous study from US in 1990's found that $19 \%$ infants born to HIV-infected mothers were premature [19].

The causes of preterm birth in this condition is still undiscoverable, even there may not be any correlation at all. Some studies that found that correlation between them, like HIV disease above stage 2, have increased risk of prematurity [20]. However, CD4 cell count or viral load still doesn't have any further association. Lack of weight gain during pregnancy can be associated with preterm and very preterm delivery. This can be one of the markers that can be used to determining maternal nutritional status [17]. This maternal nutrition relationship has been also reinforced by the evidence from van der Broek et al. that found maternal weight played a significant role in the risk of preterm birth either early or late preterm [21]. For the odds of preterm birth from underweight patient (BMI $<18.5$, even in controlled HIV positive status) has increased nearly three- fold, while the odds of late preterm were decreased if patient gained weight or her BMI [21]. However this low weight gain from mothers can be due to reverse causality, it need to investigate whether this low weight gain caused the preterm labor or this preterm labor led to less time for mother to gain a weight.

Apart from these findings, there were also contradictory studies against them. Still remains controversy about whether HAART (highly active anti-retroviral therapy) or any certain classes of ARV increase the risk of preterm birth or not [22], it makes a further study to assess direct HIV infected pregnancy on gestation at birth cannot give accurate results. Other studies from van den Broek et al. found no evidence that HIV status contributes to the risk of preterm birth [21]. Others found that HIV status increases the risk of SGA, not preterm birth [23]. Secondary infections and other medical conditions (tuberculosis, anemia) prior or started in early pregnancy have been shown to be any detrimental factors associated with SGA and preterm delivery [24] [25] [26].

Limitations from our study, we recognized several things that need to be improved for future research. Because this study only described a condition that happened in our hospital, we only use secondary data for giving an overview about this condition in our hospital. We hope further studies can use statistical analysis to gain a significant results and widely useful by other else. Our indeterminate results, missing data, or data outliers, we only resolve it temporarily by classifying it into exclusion criteria. For next, we will improve our ability to check whether the patient data is complete or not as may be required for further research.

Despite of all fetal outcomes resulted from HIV pregnancy, prevention transmission from mother to fetus can be reached by several ways. Determining other medical condition and coinfections variables, needed to make sure its contribution on fetal outcomes on HIV positive patients. From our study, we concluded the incidence of delivery with HIV/AIDS tend to increase every year. Preterm labor has the highest morbidity on fetal outcomes in our hospital. For future research, it's important to do a routine inspection for every pregnant woman regardless her HIV status. So this will be in line to support the WHO's guide for 
prevention of mother-to-child transmission (PMTCT).

\section{References}

[1] Collaborators, G.H., Wang, H., Wolock, T.M., Carter, A., Nguyen, G., Kyu, H.H., et al. (2016) Estimates of Global, Regional, and National Incidence, Prevalence, and Mortality of HIV, 1980-2015: The Global Burden of Disease Study 2015. The Lancet $H I V$, 3, e361-e387. https://doi.org/10.1016/S2352-3018(16)30087-X

[2] Kementerian Kesehatan Republik Indonesia (2016) Laporan HIV AIDS 2016. http://www.aidsindonesia.or.id/ck_uploads/files/Laporan\%20HIV\%20AIDS\%20TW\%202 \%202016.pdf

[3] Kementerian Kesehatan Republik Indonesia (2014) Pedoman Pelaksanaan Pencegahan Penularan HIV dan Sifilis dari Ibu ke Anak Bagi Tenaga Kesehatan, Jakarta.

[4] Lawn, J.E., Cousens, S. and Zupan, J. (2005) Lancet Neonatal Survival Steering T. 4 Million Neonatal Deaths: When? Where? Why? Lancet, 365, 891-900.

https://doi.org/10.1016/S0140-6736(05)71048-5

[5] Slyker, J.A., Patterson, J., Ambler, G., Richardson, B.A., Maleche-Obimbo, E., Bosire, R., et al. (2014) Correlates and Outcomes of Preterm Birth, Low Birth Weight, and Small for Gestational Age in HIV-Exposed Uninfected Infants. BMC Pregnancy and Childbirth, 14, 7. https://doi.org/10.1186/1471-2393-14-7

[6] Kind, C., Rudin, C., Siegrist, C.A., Wyler, C.A., Biedermann, K., Lauper, U., et al. (1998) Prevention of Vertical HIV Transmission: Additive Protective Effect of Elective Cesarean Section and Zidovudine Prophylaxis. Swiss Neonatal HIV Study Group. AIDS, 12, 205-210. https://doi.org/10.1097/00002030-199802000-00011

[7] Mandelbrot, L., Le Chenadec, J., Berrebi, A., Bongain, A., Benifla, J.L., Delfraissy, J.F., et al. (1998) Perinatal HIV-1 Transmission: Interaction between Zidovudine Prophylaxis and Mode of Delivery in the French Perinatal Cohort. Journal of the American Medical Association, 280, 55-60. https://doi.org/10.1001/jama.280.1.55

[8] European Mode of Delivery C (1999) Elective Caesarean-Section versus Vaginal Delivery in Prevention of Vertical HIV-1 Transmission: A Randomised Clinical Trial. Lancet, 353, 1035-1039. https://doi.org/10.1016/S0140-6736(98)08084-2

[9] International Perinatal HIVG, Andiman, W., Bryson, Y., de Martino, M., Fowler, M., Harris, D., et al. (1999) The Mode of Delivery and the Risk of Vertical Transmission of Human Immunodeficiency Virus Type 1-A Meta-Analysis of 15 Prospective Cohort Studies. The New England Journal of Medicine, 340, 977-987. https://doi.org/10.1056/NEJM199904013401301

[10] Gilbert, L. and Walker, L. (2010) My Biggest Fear Was That People Would Reject Me Once They Knew My Status...: Stigma as Experienced by Patients in an HIV/AIDS Clinic in Johannesburg, South Africa. Health \& Social Care in the Community, 18, 139-146. https://doi.org/10.1111/j.1365-2524.2009.00881.x

[11] Vithayachockitikhun, N. (2006) Family Caregiving of Persons Living with HIV/ AIDS in Thailand: Caregiver Burden, an Outcome Measure. International Journal of Nursing Practice, 12, 123-128. https://doi.org/10.1111/j.1440-172X.2006.00560.x

[12] Sociological Association (2007) Vulnerability Assessment of People Living with HIV (PLHIV) in Turkey. United Nations Development Programme, Ankara.

[13] Ramchandani, S.R., Mehta, S.H., Saple, D.G., Vaidya, S.B., Pandey, V.P., Vadrevu, R., et al. (2007) Knowledge, Attitudes, and Practices of Antiretroviral Therapy among HIV-Infected Adults Attending Private and Public Clinics in India. AIDS Patient Care STDS, 21, 129-142. https://doi.org/10.1089/apc.2006.0045

[14] Kose, S., Mandiracioglu, A., Mermut, G., Kaptan, F. and Ozbel, Y. (2012) The Social 
and Health Problems of People Living with HIV/AIDS in Izmir, Turkey. The Eurasian Journal of Medicine, 44, 32-39. https://doi.org/10.5152/eajm.2012.07

[15] WHO ANC Guidelines. Focused Antenatal Care (ANC): The Four-Visit ANC Model Outlined in WHO Clinical Guidelines.

http://www.who.int/pmnch/media/publications/aonsectionIII_2.pdf

[16] Liu, L., Johnson, H.L., Cousens, S., Perin, J., Scott, S., Lawn, J.E., et al. (2012) Global, Regional, and National Causes of Child Mortality: An Updated Systematic Analysis for 2010 with Time Trends since 2000. The Lancet, 379, 2151-2161.

[17] Zack, R.M., Golan, J., Aboud, S., Msamanga, G., Spiegelman, D. and Fawzi, W. (2014) Risk Factors for Preterm Birth among HIV-Infected Tanzanian Women: A Prospective Study. Obstetrics and Gynecology International, 2014, Article ID: 261689. https://doi.org/10.1155/2014/261689

[18] Ezechi, O.C., David, A.N., Gab-Okafor, C.V., Ohwodo, H., Oladele, D.A., Kalejaiye, O.O., et al. (2012) Incidence of and Socio-Biologic Risk Factors for Spontaneous Preterm Birth in HIV Positive Nigerian Women. BMC Pregnancy Childbirth, 12, 93. https://doi.org/10.1186/1471-2393-12-93

[19] Martin, R., Boyer, P., Hammill, H., Peavy, H., Platzker, A., Settlage, R., et al. (1997) Incidence of Premature Birth and Neonatal Respiratory Disease in Infants of HIV-Positive Mothers. The Pediatric Pulmonary and Cardiovascular Complications of Vertically Transmitted Human Immunodeficiency Virus Infection Study Group. The Journal of Pediatrics, 131, 851-856.

[20] Yu, L., Li, W.Y., Chen, R.Y., Tang, Z.R., Pang, J., Gui, X.Z., et al. (2012) Pregnancy Outcomes and Risk Factors for Low Birth Weight and Preterm Delivery among HIV-Infected Pregnant Women in Guangxi, China. Chinese Medical Journal, 125, 403-409.

[21] Van den Broek, N.R., Jean-Baptiste, R. and Neilson, J.P. (2014) Factors Associated with Preterm, Early Preterm and Late Preterm Birth in Malawi. PLoS ONE, 9, e90128. https://doi.org/10.1371/journal.pone.0090128

[22] Kourtis, A.P. and Fowler, M.G. (2011) Antiretroviral Use during Pregnancy and Risk of Preterm Delivery: More Questions than Answers. The Journal of Infectious Diseases, 204, 493-494. https://doi.org/10.1093/infdis/jir318

[23] Ndirangu, J., Newell, M.L., Bland, R.M. and Thorne, C. (2012) Maternal HIV Infection Associated with Small-for-Gestational Age Infants but not Preterm Births: Evidence from Rural South Africa. Human Reproduction, 27, 1846-1856. https://doi.org/10.1093/humrep/des090

[24] Verhoeff, F.H., Brabin, B.J., van Buuren, S., Chimsuku, L., Kazembe, P., Wit, J.M., et al. (2001) An Analysis of Intra-Uterine Growth Retardation in Rural Malawi. European Journal of Clinical Nutrition, 55, 682-689. https://doi.org/10.1038/sj.ejcn.1601200

[25] Noble, A., Ning, Y., Woelk, G.B., Mahomed, K. and Williams, M.A. (2005) Preterm Delivery Risk in Relation to Maternal HIV Infection, History of Malaria and Other Infections among Urban Zimbabwean Women. Central African Journal of Medicine, 51, 53-58.

[26] Watson-Jones, D., Weiss, H.A., Changalucha, J.M., Todd, J., Gumodoka, B., Bulmer, J., et al. (2007) Adverse Birth Outcomes in United Republic of Tanzania-Impact and Prevention of Maternal Risk Factors. Bulletin of the World Health Organization, 85, 9-18. https://doi.org/10.2471/BLT.06.033258 
Submit or recommend next manuscript to OALib Journal and we will provide best service for you:

- Publication frequency: Monthly

- 9 subject areas of science, technology and medicine

- Fair and rigorous peer-review system

- Fast publication process

- Article promotion in various social networking sites (LinkedIn, Facebook, Twitter, etc.)

- Maximum dissemination of your research work

Submit Your Paper Online: Click Here to Submit

Or Contact service@oalib.com 